\title{
A Tension in Pragmatist and Neo-Pragmatist Conceptions of Meaning and Experience
}

James R. O'Shea

\section{OpenEdition}

\section{Journals}

Electronic version

URL: http://journals.openedition.org/ejpap/297

DOI: 10.4000/ejpap.297

ISSN: 2036-4091

\section{Publisher}

Associazione Pragma

Electronic reference

James R. O'Shea, «A Tension in Pragmatist and Neo-Pragmatist Conceptions of Meaning and Experience », European Journal of Pragmatism and American Philosophy [Online], VI-2 | 2014, Online since 24 December 2014, connection on 20 April 2019. URL : http://journals.openedition.org/ ejpap/297 ; DOI : 10.4000/ejpap.297

\section{(c) (i) (9)}

Author retains copyright and grants the European Journal of Pragmatism and American Philosophy right of first publication with the work simultaneously licensed under a Creative Commons AttributionNonCommercial-NoDerivatives 4.0 International License. 


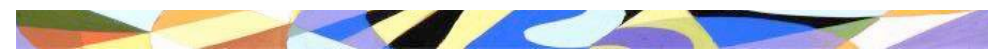

EUROPEAN JOURNAL OF PRAGMATISM AND AMERICAN PHILOSOPHY

COPYRIGHT C 2009 ASSOCIAZIONE PRAGMA

James R. O'Shea*

\title{
A Tension in Pragmatist and Neo-Pragmatist Conceptions of Meaning and Experience
}

\begin{abstract}
This paper examines a lasting tension in pragmatism between broadly functionalist outlooks on meaning and a primacy placed on what can be revealed by direct experiential or practical encounters. Both the inferentialist and experiential emphases can be traced back to Peirce's original pragmatic maxim. Here the tension is examined first in William James's insightful views on intentionality and experience, followed by a diagnosis of the problem as it has arisen in neopragmatist debates concerning the nature of perceptual knowledge in Rorty and Brandom and their critics. In the end the paper sketches the general form of a resolution of the tension that is consistent with both of these core emphases in the pragmatist tradition.
\end{abstract}

There has been an enduring tension in the pragmatist tradition, I want to suggest, between the predominant pragmatist conceptions of meaning that broadly reflect C.S. Peirce's pragmatic maxim on the one hand, and on the other hand the resulting emphasis within pragmatism on what Kant called "the fruitful bathos of experience" (2002 4: 373). In what follows I examine the tension as it arises, first, in key themes concerning meaning (or intentionality) and experience in selected works of William James, particularly in relation to what he calls "the cognitive relation". I then find the tension in neo-pragmatist views on perceptual knowledge and trace it to a plausible tight connection between the pragmatic maxim and the rejection by pragmatists such as Peirce, Rorty, and Brandom of what Sellars called the "myth of the given". However, many recent pragmatists have understandably expressed dissatisfaction with the resulting minimalist conception of experience to be found in Rorty and Brandom, however. I end with a brief diagnosis of the tension that points to the general form of a satisfactory resolution, one that would be consistent with both of these core emphases within the pragmatist tradition.

\section{The Pragmatic Maxim and Conceptual Content}

Pragmatism traces one of its most important origins to Peirce's early formulation of the pragmatic maxim in his 1878 essay, "How to make our ideas clear". As a method for clarifying the conceptual content of our intellectual ideas, Peirce's maxim (or more precisely in that essay, "the rule for attaining the third grade of clearness of apprehension") prescribes the following: "Consider what effects, which might conceivably have practical bearings, we conceive the object of our conception to have. Then, our conception of these effects is the whole of our conception of the object" (Peirce 1992: 132). While the pragmatic maxim or "test" has of course been disputed on this and other formulations by pragmatists, it reflects an enduring pragmatist

*University College Dublin [jim.oshea@ucd.ie] 
conviction that, as Peirce also puts it, "there is no distinction of meaning so fine as to consist in anything but a possible difference of practice" (Peirce 1992: 131); or as he later frames it in 1903, "pragmatism teaches us [that] what we think is to be interpreted in terms of what we are prepared to do" (Peirce 1998: 142). Those acquainted with Brandom's normative "inferentialist" semantics, developed from Sellars, will be aware of at least one sophisticated contemporary pragmatist way in which to work out the latter idea - that is, the idea that the intentional contents of our thoughts "is to be interpreted in terms of what we are prepared to do".

The contents of our concepts of objects, as thus intended to be clarified by Peirce's pragmatic maxim, should be seen, as I think most pragmatists have seen it, as a development of Kant's understanding of concepts as rules that in some sense legislate for possible experience - if not for "all possible experience", then (as C. I. Lewis argued) for the possible experience of any object of the type defined by a given concept. Roughly put, on this view concepts function in our judgments as rules determining the relevant necessities and possibilities in any experience of an object that is to be of the kind that is (thereby) specified in the given concept. Pragmatists stress that concepts, so conceived, embody implicit hypotheses in relation to the course of future experience and action, as reflected in our commitments in practice to the corresponding patterns of inference and action. Meaning or conceptual content on this general pragmatist outlook - or so I will assume it to be - is constituted however flexibly and implicitly by norms pertaining to what must, may, or ought to follow in a possible experience of or action involving an object of that kind. We will find illustrations of this general pragmatist outlook on meaning in the next section on James.

This general approach to understanding of conceptual content in terms of normative rules or functions promises to provide an account of both the generality and the counterfactual force of concepts that pragmatists argue is unattainable on classical empiricist accounts and that tends to be rendered mysterious on classical rationalist and nativist accounts. For present purposes my claim is that this is the general spirit in which theories of meaning and conceptual content have tended to develop within the pragmatist tradition: for example, in the emphases in Peirce and Brandom on the primacy of norms of inference in determining conceptual content, and in James and Lewis on concepts as functional "leadings" and lawful hypotheses with respect to future experience. At the risk of overgeneralization I will characterize this as the broadly inferentialist or functionalist conception of meaning and conceptual content that is predominant, in a variety of forms, in the pragmatist tradition. I have elsewhere offered a more detailed account of this outlook on meaning as it is found in Sellars's work in particular (O'Shea 2007: Chapters 3-4).

What I want to argue here in relation to James's pathbreaking investigations into the nature of intentionality is that the fruitful pragmatist line of thought sketched above is liable to generate a tension with the resulting ways in which some pragmatists, in this case James, have sought to stress the primacy of experience in accounting for the intelligibility of our thoughts and actions. 


\section{A Tension in James's Accounts of Intentionality and Experience}

As Russell did soon after, James distinguished between two fundamental kinds of knowledge: knowledge by direct acquaintance with something and (what James calls) knowledge about something ${ }^{1}$. Knowledge about something is conceptual knowledge, where for instance one is able correctly to classify or describe an object one has never experienced directly. To have knowledge by acquaintance with something, on the other hand, is a matter of being directly perceptually aware of the qualitative nature of some reality, and for James this is to be understood in such a way that acquaintance provides us with a form of knowledge that is more basic than conceptual or propositional knowledge. He puts it as follows in 1890 in The Principles of Psychology:

I am acquainted with many people and things, which I know very little about, except their presence in the places where I have met them.I know the color blue when I see it, and the flavor of a pear when I taste it...but about the inner nature of these facts or what makes them what they are, I can say nothing at all. I cannot impart acquaintance with them to anyone who has not already made it himself. I cannot describe them, make a blind man guess what blue is like...All the elementary natures of the world, its highest genera, the simple qualities of matter and mind, together with the kinds of relation that subsist between them, must either not be known at all, or known in this dumb way of acquaintance without knowledge-about. (PP: 217)

On this conception, our knowledge of "the simple qualities [and relations] of matter and mind" is an ineffable (or "dumb") direct knowledge by acquaintance that is independent of any conceptual knowledge, i.e. "without knowledge-about" in James's sense.

This conception of concept-independent knowledge by means of an ineffable direct acquaintance with the nature of a given reality will of course be an aspect of James's account of cognition - one which takes different forms in different periods of his thought - that will ostensibly collide with the neo-pragmatist embrace by Rorty and Brandom of Sellars's famous rejection of the myth of the given. What the latter thinkers argue is false (a "myth") is, inter alia, the idea that any such nonconceptual item or process or apprehension, whether conscious or unconscious, could be sufficient by itself to constitute an instance of perceptual knowledge of any object or property as such, however necessary such processes or items might be for specific kinds of cognition. Furthermore, the roles played by the "given" can be problematic, from this perspective, even on those views in which it is denied that the given by itself provides knowledge (though this is a more complex dispute, as for example in the case of C. I. Lewis on the given to be mentioned briefly below).

What Sellars himself objected to was not the idea that perceptual knowledge is in some appropriately contextualized sense "foundational" for empirical knowledge

1. Cf. James, The Meaning of Truth (MT:17-18); and, The Principles of Psychology (PP: 217-18). At PP 217n James refers the distinction to John Grote, Exploratio Philosophica, 60; and also to H. Helmholtz, Popular Scientific Lectures, London, 308-9. The discussion of the distinction at MT 17-18 is from James's rich 1884-5 article, "The Function of Cognition". 
(EPM: §38), nor that it is "direct" (i.e., non-inferential), nor even that at some level it involves non-conceptual representational content (as we shall see). In fact Sellars himself defended versions of each of those ideas. What he objected to was the idea that any episode or state could constitute an item of knowledge, or reveal the "nature of a reality", or more basically, have any objective intentional purport (in the relevant sense), and yet not be conceived by the knower in such a way as to have the effect of "placing" that event or state in what Sellars called "the logical space of reasons, of justifying and being able to justify what one says" (EPM: §36). While Sellars extends this account beyond our overt linguistic practices ("what one says") to our inner thoughts and experiences, too, it remains true on his extended view, as it does on Rorty's and Brandom's neo-pragmatist outlooks as well, that the relevant conceptual capacities required are fundamentally discursive in nature. Or as Sellars stated what he called his "psychological nominalism" in quite strong form ${ }^{2}$ in EPM: "all awareness of sorts, resemblances, facts, etc., in short, all awareness of abstract entities - indeed all awareness even of particulars - is a linguistic affair" (EPM: §29).

There is much dispute concerning the arguments that are supposed to show that the appeal to the given in the relevant sense either is or must be a myth ${ }^{3}$. What I will now support is the more modest claim that there are considerations internal to James's views that lead him (and by implication, many other pragmatists) to embrace something akin to the inferentialist or functionalist conception of meaning outlined earlier, and that this, as anticipated, becomes a source of internal tension in James's accounts of meaning and experience.

For in fact the tension I want to focus on arises not solely in relation to James's various accounts of perceptual acquaintance or immediate "intuition" (as he elsewhere calls it), but also in a related way in his searching attempts to explain the puzzling phenomenon of intentionality or "aboutness" more generally ${ }^{4}$. James grappled throughout his writings with the general question of what it is to have an external object "in mind" - whether it be an object of perception or of thought, and whether it amount to knowledge or not. Throughout his career James held that the intentional relation presents mysteries that can be resolved only by means of a certain shift in perspective. The problem is put clearly in the following passage from his 1895 article "The Knowing of Things Together" (reprinted in The Meaning of Truth as "The Tigers in India”):

Suppose to fix our ideas, that we take first a case of conceptual knowledge; and let it be our knowledge of the tigers in India, as we sit here. Exactly what do we mean by

2. In Section IV below it will be noted that Sellars in "Mental Events" (1981) broadened his conception of object cognition to include what he calls "animal representational systems" in ways that provide additional non-linguistic representational resources bearing on EPM's "psychological nominalism". For further details see O'Shea 2012 and (2007: Chapter 5).

3. For a recent rejection of such arguments from a pragmatist perspective, see Aikin, 2009. I offer an account of Sellars on the myth of the given and the "space of reasons" outlook on knowledge in O'Shea (2007: Chapter 5).

4. See Henry Jackman, "James' Pragmatic Account of Truth and Intentionality" (1998) for what I take to be an insightful treatment of James' account of intentionality and its relationships to his pragmatist conception of truth. 
saying that we here know the tigers? [...]. Most men would answer that what we mean by knowing the tigers is having them, however absent in body, become in some way present to our thought; or that our knowledge of them is known as presence of our thought to them. A great mystery is usually made of this peculiar presence in absence; and the scholastic philosophy, which is only common sense grown pedantic, would explain it as a peculiar kind of existence, called intentional inexistence, of the tigers in our mind.At the very least, people would say that what we mean by knowing the tigers is mentally pointing towards them as we sit here.But now what do we mean by pointing, in such a case as this? What is the pointing known-as here? (MT: 33-4)

The reference to what such a "pointing" is really "known-as here" is a Jamesean phrase signaling that the ostensibly mysterious relation of intentionality is a phenomenon ripe for an application of the clarifying pragmatic maxim. What actual or possible "effects" on our practices or on our further conceptions are entailed by our application of such concepts as, for example, "x means y", or "Jones has y "in mind", and so on? James in his various writings held that there have been three main alternative understandings of "this peculiar presence in absence".

First, as in the passage above (with reference to "most men"), there is the view of common sense, along with, as James sees it, its more refined re-articulation in a long and varying philosophical tradition ("common sense grown pedantic", as James puts it in relation to "scholastic philosophy" above). In this connection he also writes of "the rooted intellectualist persuasion that, to know a reality, an idea must in some inscrutable fashion possess or be it" (MT: 114). The term "intentional inexistence" had, of course, been used by Brentano in his Psychologie, a work that James cites favorably a few times in his own Psychology, but not in relation to the notion of "intentional inexistence". In using that phrase in the passage above James would presumably place the following famous characterization of intentionality by Brentano in this first category, as a scholastic or "college-trained" 5 refinement of common sense:

Every mental phenomenon is characterised by what the Scholastics of the middle ages called the intentional (or mental) inexistence of an object, and what we might call, though not wholly unambiguously, reference to a content, direction toward an object (which is not to be understood here as meaning a thing [eine Realität]), or immanent objectivity.Every mental phenomenon includes something as object within itself [...]. This intentional inexistence is characteristic exclusively of mental phenomena. No physical phenomenon exhibits anything like it. (Brentano, 1973: 88-9)

So then, we can have the tigers in India in mind even in their absence, or even if they do not exist at all.How is that possible? James seems to think that the ancients, the scholastics, common sense, and (I have conjectured) Brentano all share a certain very general presupposition concerning the nature of intentionality.

Consider the classical Aristotelian idea that in cases of knowledge, crudely put, the mind in some sense has the object's intelligible form in abstraction from its matter, so

5. James remarks that scholasticism is "common sense's college-trained younger sister" in Lecture V of his Pragmatism (P: 92). 
that there is an "identity of form" shared by the knower and the known.From James's perspective, such formal schemas either do not succeed in taking us beyond the initial puzzle with which we started (that is, the puzzle as to how it is that in conceiving of or knowing an object we somehow "have" the nature of the object in mind without having the object itself in our mind; the recapitulating answer offered here is that we "have its form without its matter"); or if, alternatively, there is appeal to inner "phantasms" in the passive intellect or in the imagination to help explain the relevant "isomorphism", then we are thereby led closer toward a representationalist conception of intentionality (about which more in a moment). As indicated above, James likewise takes the philosopher's notion of the "intentional inexistence" of the object in the mind to be only a more refined articulation of common sense notions. The common sense or unreflective view of the cognitive relation is in effect that the mind simply performs what James calls "a self-transcending leap" across whatever "epistemological gulf" philosophers might assume separates subjects from objects. That is, the mental just is the sort of thing that can "reach out to" or "direct itself toward" objects and thereby make them "present in their absence". Following James, I will risk over-simplification by lumping these admittedly heterogeneous considerations together under the heading of the "traditional" or "common sense" account of the intentional or cognitive relation.

At the close of the nineteenth century James finds two main alternatives to the traditional account. One is the approach of such absolute idealists as James's friend and colleague Josiah Royce, along with F. H. Bradley and many others. In A Pluralistic Universe James examines in some detail the absolute idealists' contention that, as he understands it, the puzzles concerning the relation between the knower and known in finite minds can ultimately be resolved only by appeal to the idea that the world exists only as the object of an infinitely knowing mind. For present purposes, however, I will turn to the remaining alternative explanation that James finds confronting him: namely, the classical empiricist appeal to "ideas" or mental images conceived as the means by which objects become present to the mind of the subject. James's criticisms of this third alternative will lead us to his own developing views on the intentional or cognitive relation.

James offers convincing objections against the classical empiricist notion that the cognitive relation is a matter of ideas or images in the mind representing external objects. In addition to raising psychological objections to "the theory of Hume and Berkeley that we can have no images but of perfectly definite things" (PP: 246), James also raises the crucial point that particular images or utterances do not determine their intended interpretation (PP: 248). He argues plausibly as follows, for instance:

When I use the word man in two different sentences, I may have both times exactly the same sound upon my lips and the same picture in my mental eye, but I may mean, and at the very moment of uttering the word and imagining the picture know that I mean, two entirely different things. (PP: 446)

I may mean, for instance, only some particular human being, or alternatively I may be intending to refer to the class of human beings. Of course, Berkeley and Hume had 
offered their own nominalistic account of how fully determinate, particular ideas or images could nonetheless "become general in their representation" as a result of various complex past associations. James argues plausibly, however, that the attempt to explain general conception in terms of resembling "ideas" plus association is doomed to failure.

The following passage gives an indication both of James's own developing view of intentionality and of how he sees it as a middle way between the traditional account and classical empiricism:

An idea neither is what it knows, nor knows what it is; nor will swarms of copies of the same "idea", recurring in stereotyped form, or "by the irresistible laws of association formed into one idea", ever be the same thing as a thought of "all the possible members" of a class. We must mean that by an altogether special bit of consciousness ad hoc. But it is easy to translate Berkeley's, Hume's, and Mill's notion of a swarm of ideas into cerebral terms, and so to make them stand for something real; and, in this sense, I think the doctrine of these authors less hollow than the opposite one which makes the vehicle of universal conceptions to be an actus purus of the soul. If each "idea" stand for some special nerve-process, then the aggregate of these nascent processes might have for its conscious correlate a psychic "fringe", which should be just that universal meaning, or intention that the name or mental picture employed should mean all the possible individuals of the class [...]. To one set of processes will correspond the thought of an indefinite taking of the extent of a word like man; to another set that of a particular taking; and to a third set that of a universal taking, of the extent of the same word. The thought corresponding to either set of processes, is always itself a unique and singular event, whose dependence on its peculiar nerve-process I of course am far from professing to explain. (PP: 451)

This notion of a "psychic fringe" is the problematic core of James's account of intentionality in PP. The hypothesis of special nerve-processes corresponding to each idea, and thereby also of a "psychic fringe" as "conscious correlate" of swarms of such processes, each then posited as corresponding to different intended logico-semantic distinctions - even if granted, these posits seem to leave the "unique and singular event" of the thought itself in roughly the same position it was on the traditional and common sense views. But it will be worth looking a bit more closely at this conception as it functions somewhat ambiguously in PP, since this will lead to the more promising lines of thought about intentionality in James's work from the perspective of the general pragmatist "functionalist" outlook on meaning discussed in section I (albeit with the anticipated tension remaining in the improved account as well).

James develops the notion of a psychic fringe in the famous "Stream of Thought" Chapter of PP. To put it in general terms, James is defending what he characterizes as the river-like continuity conception of thought as against the atomism of much traditional psychology. He sees the science of psychology as properly starting out from the realist assumption that there is an external world on the one hand, and introspected states of consciousness on the other, and that the latter are somehow capable of "knowing" the former. When he comes to investigate what really are the contents or objects of our thoughts, however, he argues in detail that thoughts understood in terms of their contents cannot be identified with any momentary psychological reality 
or state. For example, James borrows from Brentano the point that "what we hear when the thunder crashes is not thunder pure, but thunder-breaking-upon-silence-andcontrasting-with-it" (PP: 234). Such perceptual phenomena have their analogue at the level of thought, James argues, in the "consciousness of the whence and the whither that always accompanies its flows" (PP: 235). His analysis eventually leads him to pick out as the most important of these phenomena the idea that any given course of thought is experienced as having a direction or intended meaning.

Hitherto, he argues, introspective psychology has tended to focus only on what he calls the "substantive" parts of the stream of consciousness - our ideas of particular objects for instance - and has consequently failed to capture the real phenomena of thought or meaning. For the latter have to do with the "transitive" or relational aspects of the stream, and in particular with what James calls feelings of relation. In characteristically metaphorical terms James contends that:

Instead of catching the feeling of relation moving to its term, we find we have caught some substantive thing, usually the last word we were pronouncing, statically taken, and with its function, tendency, and particular meaning in the sentence quite evaporated. The attempt at introspective analysis in these cases is in fact like seizing a spinning top to catch its motion, or trying to turn up the gas quickly enough to see how the darkness looks. (PP: 237)

And further on he writes: "The truth is that large tracts of human speech are nothing but signs of direction in thought, of which direction we nevertheless have an acutely discriminative sense, though no definite sensorial image plays any part in it whatsoever [...]. If we try to hold fast the feeling of direction, the full presence comes and the feeling of direction is lost" (PP: 245).

It is again difficult to see, however, how the notion of an uncatchable but inarticulately sensed "feeling of direction" in thought would be an improvement over the traditional idea that a thought is about its object in virtue of a kind of "mental pointing", without this collapsing into a non-atomistic but still implausible relational version of the classical empiricist emphasis on "felt processes". James's own general diagnosis is that on the one hand the sensationalists, failing to find any "coarse feelings" or images corresponding to the "directional" aspects of the stream of consciousness, end up restricting themselves only to resemblances among separate existences or ideas (PP: 237). On the other hand the more intellectualist thinkers, "equally unable to point to any distinct substantive feelings" in which such directional relations might consist, have generally responded by assigning them to "an actus purus of Thought, Intellect, or Reason, all written with capitals and considered to mean something unutterably superior to any fact of sensibility whatever" (PP: 237-8). But James's own primary response to the problem in the $\mathrm{PP}$ is not very satisfying either. His primary suggestion seems to be that the reason we cannot locate an obvious feeling or state in which the intentional direction of our thought consists is the fact that it really consists in a more subtle and elusive feeling, a "feeling of relation" or "feeling of tendency": 
Let us use the words psychic overtone, suffusion, or fringe, to designate the influence of a faint brain-process upon our thought, as it makes us aware of relation and objects but dimly perceived. If we then consider the cognitive function of different states of mind, we may feel assured that the difference between those that are mere "acquaintance", and those that are "knowledges-about"...is reducible almost entirely to the absence or presence of psychic fringes or overtones. Knowledge about a thing is knowledge of its relations. Acquaintance with it is limitation to the bare impression which it makes. Of most of its relations we are only aware in the penumbral nascent way of a "fringe" of unarticulated affinities about it. (PP: 249-50)

As we have seen, it is supposed to be some sort of conscious feeling (or "fringe" or "halo") surrounding our consciousness of a word that makes the difference between intending a word to refer to a class as opposed to an individual, for example; and we saw James also add that this difference in feeling is supposed somehow to result from differentially waxing and waning brain-processes, which themselves, he occasionally hints, are due in large part to past associations.

So while James argues quite effectively in PP that the cognitive relation or meaning relation does not plausibly consist either in a complex set of associated images or in an original act of pure intellect, in that work he nonetheless doggedly insists that such meaning must consist in some felt-character or other. The intended meaning consists in "the halo, fringe, or scheme in which we feel the words to lie" (PP: 251). "The dynamic meaning" of a word in a sentence, he suggests, "is usually reduced to the bare fringe we have described, of felt suitability or unfitness to the context and conclusion" (PP:255). From the perspective of the "inferentialist" or normative functionalist outlook on meaning and conceptual content briefly sketched in the previous section, however, it would seem that James in PP has thus taken two important steps forward but then one step backward. Granted that neither mental images nor "pure intellectual acts" determine their own interpretation - the two steps forward - the same would seem to apply to James's own "feelings of direction" in our thought. In PP James is firm on the point, however: "The most important element of these fringes is, I repeat, the mere feeling of harmony or discord, of a right or wrong direction in the thought" (PP: 251). But from the perspective of the more general pragmatist outlooks on meaning noted earlier one wants to object that the normative dimension of intentionality to which James here refers is not the sort of thing that could be introspected as a felt-character of consciousness, even if the latter is conceived as a "flowing feeling" rather than a "static image". For example, the characteristic feeling of understanding or meaning, whatever that is supposed to be, would presumably be the sort of thing that could in principle be present in someone who does not succeed in "meaning the intended object", in cases where the "whence's and whither's" of thought (to echo James's insightful phrase) are not properly grounded in practice in the sorts of external environmental realities that the thought is supposed to be "about"6.

6. See Putnam (1981: Chapter 1), particularly in the respects in which he takes himself to be adapting pragmatist semantic insights from the later Wittgenstein. For a more detailed exploration of the influence of James on Wittgenstein, one that emphasizes aspects of pragmatist convergence in their thinking, see Goodman 2002. 
It is no doubt partly James's focus on the introspective methods that he argues are appropriate to psychology that encourages his awkward attempt to squeeze the relational whence's and whither's of conception - which from the more general pragmatist perspective on meaning represent potential insights - into a kind of feeling of direction. In the famous early Chapter of the Principles called "The Methods and Snares of Psychology" James had laid it down that in psychology "Introspective Observation is what we have to rely on first and foremost and always" (PP: 185). The fruit of that postulate is that James is prevented in the Psychology from fully developing the functionalist semantic insights that nonetheless make their presence felt throughout the book.

For a further example, after successive attempts to bring his readers to an introspective awareness of their cognitive feelings of tendency or direction, James raises the question of whether such transitive relations could be felt in the same way by two people one of whom is highly deficient in the ability to call up visual images or any other sensory imagery - who mostly "thinks in words", as we say. He describes a case of someone who is unable to visualize or picture such scenes as their morning's breakfast table but who is quite able to report verbally, in correct detail, how the various items had been arranged on the table. James then comments as follows:

The mind-stuff of which this "knowing" is made seems to be verbal images exclusively. But if the words "coffee", "bacon", "muffins", and "eggs" lead a man to speak to his cook, to pay his bills, and to take measures for the morrow's meal exactly as visual and gustatory memories would, why are they not, for all practical intents and purposes, as good a kind of material in which to think? In fact, we may suspect them to be for most purposes better than terms with a richer imaginative coloring. The scheme of relationship and the conclusion being the essential things in thinking, that kind of mind-stuff which is handiest will be the best for the purpose. Now words, uttered or unexpressed, are the handiest mental elements we have. (PP: 256)

Here James moves toward two views characteristic of the general pragmatist or "functionalist" conceptions of meaning and conceptual content sketched in section I: first, the idea that what is essential to thought is not any occurrent or introspectible character of consciousness but rather the relational whence's and whither's of perception, action, and inference; and second, that the nature of intentionality has more to do with where thought actually or potentially "leads", with respect to further thought and action, than it does with any inchoate feeling of thought's destiny. Nonetheless, in the PP, and again even in this very context, it is the feelings of relation that continue to hold the primary focus for James: as he remarks in relation to "Hegel's celebrated dictum that pure being is identical with pure nothing", when words are properly taken, not statically as in that dictum, but rather "dynamically, or as significant, - as thought -, their fringes of relation, their affinities and repugnances, their function and meaning, are felt and understood to be absolutely opposed" (PP: 256).

In James's later writings there are signs of an increasing emphasis on pragmatic function in explaining the "relation" of intentionality, rather than a primary grounding in any accompanying "feelings of direction", although the tension between meaning 
as felt experience and meaning as function persists in one form or another throughout his works. Whereas James in PP was prepared to say that the cognitive relation is "reducible almost entirely" to the "psychic fringe" or "feeling of relation" that surrounds an image or word (PP: 249-50), by the turn of the century he holds that it is "the experienceable environment" that is "the vehicle or medium connecting knower with known" and that "yields the cognitive relation" (MT: 32n)7. Somehow the "intentional inexistence" of the tigers in India, their mysterious "presence in absence" to our minds, is now to be explained primarily in terms of what he speaks of as concrete natural relations rather than primarily by any feelings of a direction in thought. To see what James has in mind we must look briefly at his mature account of our conceptual knowledge about objects.

By the time of his late work, Some Problems of Philosophy, written during the year or so before his death in 1910, James had come to explain the nature of conceptual representation more explicitly in terms of functional relations. Using the term "content" or "substantive content" in these contexts not to refer to conceptual or intentional content, as we would tend to use it, but rather to describe the "static" intrinsic and structural qualities of whatever images or other items might happen to accompany or embody our concept of a given kind of thing, James writes that in order "to understand the nature of concepts better we must...distinguish their function from their [structural] content" (SPP: 36 - "structural" is my addition). He argues that while a concept may in one sense be identified with the relevant word itself, for example, or even with whatever vague images or "substantive content" may be associated with the given word, what gives the concept its meaning is its use as "an instrument for symbolizing certain objects" (SPP: 36). In the case of some concepts, he argues, "their whole value seems to be functional": they "suggest no definite picture" and "their significance seems to consist entirely in their tendency, in the further turn which they may give to our action or our thought" (SPP: 37). Here the earlier emphasis in PP on "feelings of tendency" is replaced by references to the dispositional tendency of a given word or image to lead regularly to various subsequent thoughts, perceptions, and actions. In cases where there are definite pictures or images associated with a given concept, James argues that while this static or "substantive content" may have some aesthetic value, the concept's real significance is determined by its relational or functional consequences:

However beautiful or otherwise worthy of stationary contemplation the substantive part of a concept may be, the more important part of its significance may naturally be held to be the consequences to which it leads. These may lie either in the way of making us think, or in the way of making us act. Whoever has a clear idea of these knows effectively what the concept practically signifies, whether its substantive content be interesting or not. (SPP: 37 )

\footnotetext{
7. Written in 1909 as an extended endnote comment on his own 1884 essay, "The Function of Cognition".
} 
Two pages further on, "what the concept practically signifies", in the above functional sense, is then identified with "the meaning of the concept", which James then relates back to the pragmatic maxim or rule itself:

The pragmatic rule is that the meaning of a concept may always be found, if not in some sensible particular which it directly designates, then in some particular difference in the course of human experience which its being true will make [...]. In obeying this rule we neglect the substantive content of the concept, and follow its function only. (SPP: 37, 38 ; italics added)

James in this later work goes on to develop a rough account of what he calls our "conceptual map-making”, whereby for example class-names for objects will come to serve as signs in our thought for the previously experienced regularities exhibited by that kind of object. Through language learning and other continuing modes of social inquiry we come to be so habituated that our patterns of inferring from term to term will more or less accurately "map" the lawlike relations that obtain among the sensible things themselves. But what James now emphasizes more clearly than he had previously in relation to the whence's and whither's of conception is that what it takes for any of one's present states, occurrent processes, or concrete items of whatever kind - whether it be a feeling, image, word, mental act, mental object, or whatever the case might be - to succeed in being about something is for one's practical tendencies of thought and action to be such that one could now go on to prove oneself, as it were, by further describing or clarifying or ultimately literally pointing (rather than "mentally pointing") in the direction of the external reality itself. To put it in blunt Jamesean terms, for one of my thoughts, utterances, or images to be about the tigers in India would be for it to be such that, all going well, it could in principle, for example, "lead me up" to the tigers in India. In the following famous passage from his 1912 Essays in Radical Empiricism, "A World of Pure Experience", James pulls together by means of an example his mature view on "what the actual meanings of the mysterious cognitive relation may be":

Suppose me to be sitting here in my library at Cambridge, at ten minutes' walk from "Memorial Hall", and to be thinking truly of the latter object. My mind may have before it only the name, or it may have a clear image, or it may have a very dim image of the hall, but such intrinsic differences in the image make no difference in its cognitive function. Certain extrinsic phenomena, special experiences of conjunction, are what impart to the image, be it what it may, its knowing office.

For instance, if you ask me what hall I mean by my image, and I can tell you nothing; or if I fail to point or lead you towards the Harvard Delta; or if, being led by you, I am uncertain whether the Hall I see be what I had in mind or not; you would rightly deny that I had "meant" that particular hall at all, even though my mental image might to some degree have resembled it. The resemblance would count in that case as coincidental merely, for all sorts of things of a kind resemble one another in this world without being held for that reason to take cognizance of one another.

On the other hand, if I can lead you to the hall, and tell you of its history and present uses; if in its presence I feel my idea, however imperfect it may have been, to have led hither and to be now terminated; if the associates of the image and of the felt hall run 
parallel [...] why then my soul was prophetic, and my idea must be, and by common consent would be, called cognizant of reality. That percept was what I meant, for into it my idea has passed by conjunctive experiences of sameness and fulfilled intention. (ERE: 28-9)

In these and similar passages James develops the pragmatic-functionalist side of his conception of the "mysterious cognitive relation" in directions that represent breakthroughs from the perspective of the sorts of contemporary pragmatist approaches to meaning referred to in the first section above. There remains the tendency even in these passages, however, to attempt to ground the account ultimately in feelings of direction and perceptual images: "I feel my idea" to be terminated in a "felt hall", writes James, and the latter "percept was what I meant". For the contemporary inferentialist pragmatist that tendency tempts to spoil the insight that the term "hall" or the concept of the hall has whatever cognitive content or meaning it does have, in my thoughts, utterances, and experiences, in virtue of the fact that the wider patterns of perceptual response, inference, and action in which they are caught up are generally as they ought to be (O'Shea 2007: Chapter 4). The tension, it would seem, is built into the twin concerns of James's pragmatism on the one hand and his "radical empiricist" conception of "pure experience" on the other. Those are not unrelated concerns in James, since it is the pragmatic maxim itself that prescribes the search for the "real effects" in experience and action that the pragmatist might take to be the key to the clarification of the meaning or conceptual content of our ideas. The tensions arise when the "effects" that are taken to be entailed by applications of and inferences involving the given concept begin to take the form of various introspected qualities or felt experiences that cannot plausibly be regarded as playing the cognitive semantic roles for which they are unfortunately volunteered by James.

The tension discussed above in relation to James's developing conceptions of intentional content and the "cognitive relation" of course becomes most taut in those places (as with his conception of "direct acquaintance" noted earlier) where James turns his attention to the ultimately ineffable and conceptually inexhaustible plenitude of sensory qualities, a "primordial flux" that James portrays us as conceptualizing now one way, now another, but never fully adequately knowing in its inner reality by such discursive means. In SPP, for example, James continues to argue that "conceptual knowledge is forever inadequate to the fullness of the reality to be known" (SPP:45), defending a thesis he calls "the insuperability of sensation": namely, "1. That concepts are secondary formations, inadequate, and only ministerial; and 2. That they falsify as well as omit, and make the flux impossible to understand" (SPP: 45). Not surprisingly, James grants that neither he nor anyone else can have anything informative to say about the supposed immediate experiences or ineffable intuitions in which such a deeper unconceptualizable revelation of the real "inner nature" of the flux is supposed to consist $^{8}$.

8. Cf. O'Shea 2000 for a more detailed account of the unsatisfactoriness of this last aspect of James's thought, which becomes most prominent in his late (Bergsonian) work, A Pluralistic Universe, but elements of which trace back throughout James's career. For an alternative, more sympathetic reading of this side of James's thought, however, see Levine (2013: 128-30). 
I think it could be shown that the tensions exhibited above are also not resolved in James's further complex doctrine, in Essays in Radical Empiricism, of a pure experience that is supposed to be "virtually both objective and subjective" yet "at its own moment actually and intrinsically neither", undergoing "retrospective" conceptual interpretation as mental or physical "while it stands, throughout the operation, passive and unchanged" (ERE: 64). However, having at this stage sufficiently exhibited in James's work the tension I have been concerned to clarify, I turn now to consider the contrasting neo-pragmatist conception of perceptual experience in Rorty and Brandom.

\section{A Neo-Pragmatist Outlook on Language, Experience, and the Given}

One of the most influential neo-pragmatist lines of thinking about meaning, knowledge, and the nature of perceptual experience traces back to Sellars's (EPM) rejection of the "myth of the given", particularly as this was interpreted and reinvigorated by Richard Rorty in his landmark work, Philosophy and the Mirror of Nature (1979), and as then put to more systematic pragmatist uses by two of Rorty's most influential students, Robert Brandom and Michael Williams ${ }^{9}$. In Chapter four of that work, entitled "Privileged Representations", Rorty presented Sellars's critique of the sensory given and Quine's critique of analyticity as both premised on a certain holistic, social view of justification that, in Rorty's hands, issues in a radically discourse-oriented and anti-representationalist philosophical outlook:

In order to defend Sellars and Quine, I shall be arguing that their holism is a product of their commitment to the thesis that justification is not a matter of a special relation between ideas (or words) and objects, but of conversation, of social practice [...]. The crucial premise of this argument is that we understand knowledge when we understand the social justification of belief, and thus have no need to view it as accuracy of representation [...] Once conversation replaces confrontation, the notion of the mind as Mirror of Nature can be discarded. (Rorty 1979: 170)

What Rorty sees as crucial in Sellars's critique of the given is his clearly distinguishing the naturalistic dimension of brute causality in the relationship between mind and world from all questions of the justification of a belief. What can support a belief is only another belief, according to Rorty, whereas a non-propositional state or event of whatever kind, whether mental or non-mental, cannot by itself provide support for anything. The give and take of reasons replaces the attempt to accurately represent or "mirror" nature, on Rorty's view.

In Brandom's sophisticated development of this groundlevel antirepresentationalist approach, an analysis of the normative framework of inferential commitments and entitlements implicit in our social practices of giving and asking for reasons is argued to be sufficent to account for the necesssary representational

9. In fact, the "minimal" pragmatist view of perception to be discussed below in relation to Rorty and Brandom traces back to what Paul Feyerabend in the 1950s called his pragmatic theory of observation. 
objectivity of our discursive practices without appealing to any primitive semantic representational or referential relations to the world. In his groundbreaking 1994 book, Making It Explicit, Brandom traces his inferentialist account of conceptual content back to Sellars:

The leading idea of the approach to content and understanding to be developed here is due to Sellars. Sellars's suggestion is that the key element missing from the parrot and the measuring instrument - the difference between merely responsive classification and conceptual classification - is their mastery of the practices of giving and asking for reasons, in which their responses can play a role as justifying beliefs and claims. To grasp or understand a concept is, according to Sellars, to have practical mastery over the inferences it is involved in - to know, in the practical sense of being able to distinguish, what follows from the applicability of a concept, and what it follows from [...]. One immediate consequence of such an inferential demarcation of the conceptual is that one must have many concepts in order to have any. (Brandom 1994: 89)

The resulting Sellarsian-inferentialist conceptions of meaning and intentionality in Brandom place his view firmly in the tradition of pragmatist outlooks on meaning as I briefly represented that tradition in section I above. What, then, of the sorts of tension we found in James's pragmatist outlook on meaning in relation to the various appeals he makes to the felt or sensuous characters of experience?

Not surprisingly, the tension is taken by Rorty and Brandom to disappear if we follow Sellars's thoroughgoing rejection of "the given" as a myth; that is, if we eschew any appeals to "experience" where this is portrayed as both non-discursive in nature and yet somehow by itself, without conceptual presuppositions, intrinsically reasongiving or reality revealing (the myths of the "epistemic given" or "categorial given" respectively $)^{10}$. In general, those who accuse defenders of the given of purveying a myth attempt to show that at some point in the appeal to the given - for example, in the form of "pure experiences", "sensory presentations", "manners of sensing", "qualia complexes", etc., whether in C. I. Lewis, in contemporary foundationalist epistemologies, or in the occasional level-mixing appeals in cognitive science implicit assumptions are made either about the epistemic role or about the type or "category" of item appealed to (e.g., as a quality or state, mental or physical, particular or universal) that are officially supposed to remain "neutral" (H. H. Price) or be "later questions" (C.I. Lewis) as far as the role of the mere "given" itself is concerned. The accuser typically attempts to show that (non-innocent) conceptions of the given in each case can be shown to vacillate between rich descriptions that presuppose conceptualizations that are inconsistent with the given's supposed independence of any such classifications, and appeals to the given (often in the same paragraph) that are so "thin" as to be vacuous without backsliding into the former presuppositions.

10. I have argued in O'Shea (2007, Chapter 5) for the importance of a distinction in Sellars (although he does not explicitly distinguish these) between the myth of the "epistemic given" and a more basic underlying myth of the "categorial given", the latter being applicable to both non-foundationalist and foundationalist appeals to the given. 
Appeals to the "given" that grant the need for conceptualization if the given is to play any role that is intelligibly non-vacuous either for the subject or in the theory - without illicitly mixing those two perspectives - need not be "mythic". Sellars's own robust theoretical posit of the nonconceptual "manners of sensing" involved in perception was intended to be just such an innocent, non-epistemic, scientificexplanatory replacement for the traditional givennist "sense-data". Such innocent conceptions of the given, however, are more often the intention than the reality in appeals to the given, as for example is arguably the case even with C.I. Lewis's account of the given as necessary but not sufficient for any instance of knowledge proper $^{11}$.

In this spirit Brandom, most recently expressed in his Perspectives on Pragmatism: Classical, Recent, and Contemporary, has followed his teacher Rorty in concluding that for philosophical purposes it is safest for pragmatists simply to shelve appeals to "experience":

I have by and large followed my teacher in rejecting the notion of experience as too burdened by noxious baggage - in particular, by the Myth of the Given - to be worth trying to recruit for serious explanatory and expressive work in Philosophy. "Experience" is not one of my words - literally: it does not occur in Making It Explicit, which contains many words. (Brandom, 2011: 197) ${ }^{12}$

Let us continue with the pragmatist emphasis on perceptual experience as our primary case, while recognizing that there are of course other crucial dimensions of "experience-as-practice" emphasized by pragmatists. What, now, is the alternative account of perception offered by Rorty and Brandom that eschews appeal to "experiences"? In the following passage Rorty again appeals to a shared Sellarsian background, in this case in relation to the nature of perception ${ }^{13}$ :

I had assumed that we Sellarsians all agreed with Armstrong, Pitcher, Dennett, et al., that perceptual experience was simply a matter of physiological events triggering a disposition to utter various non-inferential reports. We all agreed, I thought, that Wittgenstein was right to reply to the question "How do you know that that is red?" with "I know English". (Rorty 2000: 186)

As worked out more systematically in Brandom's "two-ply" Sellarsian account of perception, and adopting Sellars's "dot quotation" device to classify normativeinferential roles, we can say that the minimal neo-pragmatist account of perception that is broadly shared by Sellars, Rorty and Brandom (Sellars adds more, as we shall see) is roughly the following: The normal adult, human visual perception of (say) a red physical object is:

11. For Sellarsian arguments to this effect, see Williams (1999: Chapter 2), and O'Shea (2007: Chapter 5).

12. Cf. Rorty on Dewey, in Rorty (1998: 297).

13. In this context Rorty is responding to Brandom's attempt to rehabilitate an innocent notion of "facts", but otherwise the two agree on the following conception of perceptual knowledge. 
(a) a conceptually contentful, rule-governed response [e.g., an · $\mathrm{x}$ is red thought],

(b) reliably caused by the appropriate corresponding object [i.e., by red objects], and

(c) causally (not epistemically) mediated by various neurophysiological processes.

I will make just a few comments on this "minimalist" neo-pragmatist account of the nature of our perceptual responses.

One central concern of Sellars's in relation to both (a) and (c) above, but a misguided concern from the perspective of Rorty and Brandom, was to provide an account of the perceived sensible qualities of physical objects that would ultimately account for what today, usually on very different grounds, goes under the headings of 'qualia' and the so-called "hard problem" of consciousness. That tangled topic will not be my concern here, although this issue does directly link Sellars's own conception of perceptual experience with similar emphases on the qualitative richness of sensory consciousness in classical pragmatism, and it is not unrelated to the different enrichment involved in Sellars's account of perceptual cognition that I will discuss in the final section.

I hold that the above minimal neo-pragmatist conception of perceptual knowledge is promising as far as accounting for the epistemic reliability, the rationality, and the conceptual content of our perceptual experiences are concerned. I also take it to be an account that is fully in harmony with the pragmatic maxim and the predominant pragmatist approaches to meaning sketched in section I. Nonetheless I think that the tension between meaning and experience in the pragmatist tradition has not gone away, and that there is something to the criticisms that have been raised by pragmatists against the minimal neo-pragmatist account of perception in Rorty and Brandom encapsulated in (a), (b), and (c). Or so I will now suggest in conclusion.

\section{Enriched Pragmatist Conceptions of Cognitive Perceptual Experience}

The general suggestion to be considered in closing is that there are intelligible pragmatist accounts of experience and action (here I will continue to focus on perceptual experience in particular) that are not adequately captured by the "minimal" neo-pragmatist "reliable conceptual-linguistic response" model of perception sketched above, but which also do not violate Peirce's pragmatic maxim understood (as it has been throughout this paper) as helpfully elucidated in the spirit of that same neo-pragmatist "inferentialist" outlook on meaning, including the rejection of the "given" as a myth. It is not easy to locate a space for such conceptions. To the extent that experience is in any respect regarded as essentially outstripping articulate conceptualization, to that extent the view will be in danger of flouting the neo-pragmatist conceptions of meaningfulness and the accompanying strictures on "givenness" that I have found reason to respect.

In his recent synoptic book, The Pragmatic Turn (2010), Richard Bernstein has continued to engage sympathetically both with the classical pragmatist stress on the richness and dynamism of experience on the one hand, and with the neopragmatist conceptions of the social-linguistic nature of meaning and knowledge in 
the "logical space of reasons" on the other ${ }^{14}$. In various ways Bernstein is sensitive to the central tension that I have been exposing, particularly in his Chapter six entitled "Experience after the Linguistic Turn". In the following passage he contends that Peirce's conception of Secondness, which "acknowledges the brute compulsiveness of experience" (Bernstein 2010: 52), not only "helps to undercut much of the sterile debate about realism and antirealism in contemporary philosophy" but also thereby reinforces the classical pragmatist emphasis on experience and thus "helps us escape from some of the dead-ends of the linguistic turn":

I don't think we need anything more than Secondness to do justice to what philosophers call their "realistic intuitions". We do not need to reify a realm of facts that exist independently of any language, thought, or inquiry. Peirce does justice to the fallibility and openness of all justificatory practices and inquiry without losing touch with a reality "that is independent of the vagaries of me and you" (Peirce 1992: 52). Contrary to the prevailing prejudice that the linguistic turn displaces old-fashioned talk about experience, Peirce's conception of experience helps us to escape from some of the dead-ends of the linguistic turn. (Bernstein 2010: 136)

However, I think Bernstein here and in his further clarifications puts the matter too strongly in claiming the sufficiency of the resistance or "Secondness" provided by experience for reinstating a "realistic" or realist pragmatist conception of experience that somehow advances beyond the limits on meaning or intelligibility imposed by the neo-pragmatist semantic descendants of the pragmatic maxim. In relation to the question of objectivity that is Bernstein's primary concern in this context, this particular way of appealing to experience underplays the importance Bernstein himself correctly places on the "progressive narrative" that he shows stretches from Peirce up to Robert Brandom's more recent linguistic conception of the "necessary structural form of objectivity" (Bernstein 2010: Chapter 5; and Brandom 1994: Chapter 8). In that progressive pragmatist narrative the issues of objectivity and meaningfulness or conceptual clarity are tightly linked, and I think this has implications for the insufficiency of Secondness to recover the richer pragmatist notions of experience that we are looking for.

Against a certain background of intelligibility Bernstein is right to stress the importance of the role played by Peircean Secondness as "the brute constraining force of experience" (Bernstein 2010: 134). Bernstein expresses the important truth contained in the idea of the "brute compulsiveness" of experience this way: "Acknowledgement of this bruteness - the way experience 'says NO!' - is required to make sense of the self-corrective character of inquiry and experimentation" (Bernstein 2010: 134). But of course as Bernstein is well aware, in rejecting the "Myth of the Given" both Peirce and Sellars hold that, as Bernstein puts it, "as soon as we raise the question, 'What constrains us?' we are dealing with Thirdness" (Bernstein 2010: 135) - that is, with inferentially articulable conceptual content, which is what in Peirce broadly corresponds to the normative-epistemic and semantic dimension of the Sellarsian

14. The following two paragraphs are adapted from the examination of Bernstein's book to be found in O'Shea 2011. 
"space of reasons". For the question of what it is in reality that our experience forces us somehow to accommodate in the process of self-correcting empirical inquiry depends entirely in this respect on the concepts that constitute this aspect of our direct perceptual experiences as cognitions of objects. All of the pragmatists, in one form another, arguably accept the force of this point from Kant, and so, I think, does Bernstein. But of course what the proper and steady recognition of this point immediately does is to land us right back - "Secondness", "Thirdness" and all - to the fundamental problem of making sense of an objective and intelligible pragmatist account of experience that somehow enriches the minimal neo-pragmatist account of perceptual experience while respecting the semantic constraints of the neo-pragmatist developments of Peirce's pragmatic maxim.

There is of course much else in Bernstein's work that seeks to develop just such notions of experience, and in fact some excellent recent articles and reviews by his former student Steven Levine directly examine some of the ways in which a broadly Deweyan outlook on experience might intelligibly address the shortcomings (along with the insights) that he finds in the neo-pragmatist conceptions of experience. In his treatments of Rorty, Brandom, and other neo-pragmatists (for example, in Levine 2012 and 2011) Levine makes use of aspects of the views of Merleau-Ponty, Hubert Dreyfus, and Dewey on embodied and socially inculcated skills and habits to develop what he calls an "inflationary" as opposed to "deflationary" conception of habits as infused with implicit norms of optimality and purposiveness. The key contention on Levine's view is that such skills and habits are implicitly and passively rational independently of the discursive conceptual abilities with which they become integrated, whereas Brandom insists on a sharp distinction that reserves rationality for the discursive. This outlook enables Levine to recover and develop broadly Deweyan, classical pragmatist conceptions of experience while being able to respect, having thus broadened, the pragmatic tradition's requirements on meaning and rational intelligibility. In structurally related though independent ways, Carl Sachs in recent and forthcoming work argues on grounds inspired by Merleau-Ponty that the emphasis placed by Sellarsians and by pragmatists on semantic intentionality within the "logical space of reasons" needs to be enriched with a more basic account of what he calls (non-semantic, non-conceptual) somatic intentionality. Similar to Levine, Sachs seeks to provide an account that emphasizes that "as rational animals, humans are both creatures of rules and of habits. The space of reasons is not only social but also embodied" (Sachs 2014: 223).

The views of Sachs and Levine, only briefly gestured at here, represent just two among many other ways in which current pragmatist thinkers are seeking to advance beyond the impasse that has emerged between those who are inspired by the classical pragmatist emphases on experience and those neo-pragmatists who stress the give and take of reasons within the logical space of reasons ${ }^{15}$. To be satisfactory for my

15. I will mention just two other recent books that I think are particularly important in relation to the tension with which this paper has been centrally concerned, and for suggesting systematic pragmatist proposals for its resolution: namely, Huw Price's Expressivism, Pragmatism and Representationalism (2013; see especially the "Postscript to Chapter 8), and Colin Koopman's Pragmatism as Transition 
present purposes, the appeals to Dewey on experience or to Merleau-Ponty on natural somatic intentionality will have to avoid - as perhaps they can - backsliding either into implicit appeals to givenness ${ }^{16}$ or into notions of teleological, bodily normativity that threaten objectionably to "re-enchant" nature when viewed critically from a Darwinian naturalist perspective. With these general concerns in mind, however, in my own writings on Sellars and on neo-pragmatism (most recently in O'Shea 2012) I have taken a slightly different Sellarsian tack. The aim is similar, however, in seeking to integrate within the neo-pragmatist inferentialist outlook on meaning a richer conception of perceptual experience in the context of our naturally purposive and embodied animality. I will just briefly sketch this conception in closing.

The idea is that what is essential to the neo-pragmatist inferentialist or "space of reasons" semantic development of Peirce's pragmatic maxim, as well as to the rejection of the myth of the given, is the contention that meaning and the possession of conceptual (and thereby representational) content in general is possible only against the background of a wider framework of normative practices that implicitly constitute the "ought-to-be's" of perceptual response, inference, and intentional action ${ }^{17}$. So far I take this to be consistent with the "minimal" conception of perceptual response in Rorty and Brandom discussed in the previous section. Sellars himself, as I mentioned, attempted to integrate within this outlook an account of qualitative sensory consciousness that, if it were successful, would link his account with some of the concerns of the classical pragmatists in relation to the "intrinsic nature" of perceptual experience (especially in James and Lewis), but without any reliance on "givenness". Setting that complex issue to one side, however, there was another way in which Sellars expanded his original account along lines that were explicitly rejected by neopragmatist Sellarsians such as Rorty and Brandom and largely ignored by most other Sellars-inspired philosophers (with such significant exceptions as Ruth Millikan and Jay F. Rosenberg) ${ }^{18}$.

There is a key underlying idea that is common to both Sellars's account of what he called, in a late article, animal representational systems ("Mental Events"), and its subsequent more robust development in Ruth Millikan's evolutionary "proper function" account of intentionality - despite these two philosophers differing sharply in their accounts of the nature of our logical-linguistic intentionality (i.e., within the "space of reasons" proper). The shared underlying idea is that the natural, non-logico-linguistic cognitive and active capacities of both human and other animal natures have their purposive significance in virtue of being embedded within a wider "space" of naturally

(2009; see especially Chapters 3 and 4)

16. Koopman (2009: Chapter 3) is helpful on this issue in relation to recent work on Dewey.

17. Cf. section one above; and for the wider background cf. O'Shea (2007: Chapters 3 and 4) on Sellars on meaning, intentionality, and normativity.

18. I briefly discuss Millikan in this particular connection in O'Shea 2012. With respect to Jay Rosenberg, I particularly have in mind his outstanding and neglected book, The Thinking Self [1986], which has fortunately recently been re-issued by Ridgeview (2008). See especially Rosenberg's accounts of animal cognition in a Sellarsian (and Kantian) spirit using the method of what he calls "logical phenomenology" (cf. Chapters 4-7; e.g., 99-100). Levine and Sachs in their work are also concerned with the possible insights in, but also limitations of, this non-conceptual dimension of Sellars's views. 
selected relations of proper functioning within which such norm-constituted cognitive significances make non-mysterious, naturalistic sense (O'Shea 2012 on Millikan and Brandom). A logical space of reasons - what Sellars (1981: §VI) calls an "Aristotelian" (logical) as opposed to a "Humean" (non-logical animal) representational system - is on Sellars's view not the only "space" of constitutive normative relations the systematic embedding within which can explain the purposiveness and directed meaningfulness including the object-representational purport - of the items so embedded. In this spirit Sellars puts forward a more general conception of pattern-embedded representational systems, based on a natural selection based conception of proper functioning, as underlying all animal representational systems:

Indeed, I propose to argue that to be a representational state, a state of an organism must be the manifestation of a system of dispositions and propensities by virtue of which the organism constructs maps of itself in its environment, and locates itself and its behavior on the map.

Such representational systems (RS) or cognitive map-makers, can be brought about by natural selection and transmitted genetically, as in the case of bees. Undoubtedly a primitive RS is also an innate endowment of human beings. The concept of innate abilities to be aware of something as something, and hence of pre-linguistic awarenesses is perfectly intelligible. (Sellars 1981: §§56-7)

Systematic embedding within a naturally selected "space" of proper functioning, on the broad Sellars-Millikan teleological conception of basic purposive animal cognition and agency, is in fundamental respects in harmony not only with the evolutionary outlooks of the classical pragmatists, but also with the holistic semantic functionalism that this paper has argued broadly (but not unequivocally) characterizes the enduring pragmatist tradition. For although in this naturalistic setting Sellars as opposed to Millikan is not attempting to explain conceptual content in biological terms (i.e., in the primary sense that, on Sellars's view, requires systematic inferential embedding within a logical space of rational proper functioning), their shared evolutionary account of the roots of our natural animal capacities similarly explicates the purposiveness and representational normativity exhibited in the animal dimensions of our rational animality through a systematic embedding within a wider "space" of proper-functional "effects" (to echo Peirce's pragmatic maxim). The shared pragmatist theme across the conceptual and the non-conceptual or animal-cognitive cases, I am suggesting, is the move to explicate both the intentional and the natural "directedness" of our experiences and our purposive activities by appeal to an integrated systematic embedding within two fundamentally different but (in our case) integrated "spaces" of normative proper functioning: the rational and the animal-natural. This is one general form of resolution of the tension between the conceptions of meaning and experience that I have argued has been an enduring characteristic of the pragmatist tradition.

David Hildebrand has recently noted the following in relation to the contemporary pragmatist, Joseph Margolis: "Linguistic pragmatists, Margolis argues, have provided no evidence for their assumption that language deserves primacy at the exclusion of experience" (italics in original), and Hildebrand then quotes the following remark 
from Margolis:

Why must we suppose, even if judgments, beliefs, reasons, and intentions are, paradigmatically, "verbal", that there are no evolutionarily plausible animal analogues of any and all such cognitive elements, inferable...from the behavior of nonlinguistic creatures? (Margolis 2002: 124; quoted in Hildebrand 2012)

I take the proposal I have sketched above to be broadly in the spirit of this remark, and to be applicable to fundamental dimensions of human cognition as well. I suspect, however, that some of the recent pragmatist philosophers influenced by Dewey or perhaps by Merleau-Ponty might hold that the Sellars-Millikan approach to our purposive and habitual non-conceptual cognitions and activities is incapable of capturing the distinctive insights of those two philosophers in particular. I take this to be an open question. My own hunch would be that the important reconciling pragmatist insights to be mined from the systematic works of those two philosophers could be understood consistently with the hypothesis offered here, namely, that all purposiveness, cognitive content, and normative significance ultimately derives, in one way or another, from the subtle integration of the two sorts of wider natural and conceptual systematic embeddings that make possible the particular cognitive lives of rational animals.

\section{References}

Aikin S. F., (2009), "Pragmatism, Experience, and the Given", Human Affairs, 19, 1.

Bernstein R. J., (2010), The Pragmatic Turn, Cambridge: Polity Press.

Brandom R. B., (1994), Making It Explicit: Reasoning, Representing, and Discursive Commitment, Cambridge, MA: Harvard University Press.

- (2011), Perspectives on Pragmatism: Classical, Recent, and Contemporary, Cambridge, MA: Harvard University Press.

Brentano F., (1973), Psychology from an Empirical Standpoint [1874], London: Routledge.

Goodman R. B., (2002), Wittgenstein and William James, Cambridge: Cambridge University Press.

Hildebrand D., (2012), “Experience or Language? Choosing Pragmatism's Central Motive", First European Pragmatism Conference, Rome, September 19-21.

Jackman H., (1998), "James' Pragmatic Account of Truth and Intentionality", Transactions of the Charles S. Peirce Society, 34, 1. 
James W., MT, 1975, The Meaning of Truth [1909], Cambridge, MA: Harvard University Press.

— P, 1975, Pragmatism [1907], Cambridge, MA: Harvard University Press.

- PP, (1983), The Principles of Psychology, Cambridge, MA: Harvard University Press.

— ERE, 1996, Essays in Radical Empiricism [1912], Lincoln and London: University of Nebraska Press.

- SPP, 1996, Some Problems in Philosophy: A Beginning of an Introduction to Philosophy [1911], Lincoln and London: University of Nebraska Press.

Kant I., (2002), Prolegomena to Any Future Metaphysics [1783], in The Cambridge Edition of the Works of Immanuel Kant: Theoretical Philosophy After 1781, Cambridge: Cambridge University Press.

Koopman C., (2009), Pragmatism as Transition: Historicity and Hope in James, Dewey, and Rorty, New York: Columbia University Press.

Levine S., (2010), "Rehabilitating Objectivity: Rorty, Brandom, and the New Pragmatism", Canadian Journal of Philosophy, 40, 4.

— (2012), "Norms and Habits: Brandom on the Sociality of Action", European Journal of Philosophy, published online May 2012, print edition forthcoming 2014.

- (2013), "Does James have a Place for Objectivity?: A Response to Misak", European Journal of Pragmatism and American Philosophy, V, 2.

Margolis J., (2002), “Dewey's and Rorty’s Opposed Pragmatisms”, Transactions of the Charles S. Peirce Society, 38, 1/2.

O'Shea J., (2000), "Sources of Pluralism in William James", in Pluralism: The Philosophy and Politics of Diversity, ed. by M. Baghramian, and A. Ingram, London: Routledge.

— (2007), Wilfrid Sellars: Naturalism with a Normative Turn, Cambridge: Polity Press.

- (2008), "American Philosophy in the Twentieth Century", in The Routledge Companion to Twentieth Century Philosophy, ed. by D. Moran, London: Routledge. 
O'Shea J., (2011), “Objective Truth and the Practice Relativity of Justification in the Pragmatic Turn", European Journal of Pragmatism and American Philosophy, III, 2.

- (2012), "Prospects for a Synoptic Vision of our Thinking Nature: On Sellars, Brandom, and Millikan", Humana Mente: A Journal of Philosophical Studies, 21.

Peirce C. S., (1992), “How to Make Our Ideas Clear” [1878], in The Essential Peirce: Selected Philosophical Writings, Volume 1 (1867-1893), ed. by N. Houser, and C. Kloesel, Bloomington: Indiana University Press.

Price H., (2013), Expressivism, Pragmatism and Representationalism, Cambridge: Cambridge University Press.

Rorty R., (1979), Philosophy and the Mirror of Nature, Princeton, NJ: Princeton University Press.

— (1982), Consequences of Pragmatism, Minneapolis: University of Minnesota.

— (1998), "Dewey Between Hegel and Darwin", in Truth and Progress: Philosophical Papers Volume 3, Cambridge: Cambridge University Press.

- (2000), "Response to Brandom", in Rorty and His Critics, ed. by Robert B. Brandom, Oxford: Blackwell.

Rosenberg J. F., (2008), The Thinking Self [1986], Atascadero, CA: Ridgeview Publishing Company.

Sachs C., (2014), "Discursive and Somatic Intentionality: Merleau-Ponty contra 'Sellars or McDowell'”, International Journal of Philosophical Studies, $22,2$.

Sellars W., EPM, (1963), "Empiricism and the Philosophy of Mind" [1956], in Science, Perception, and Reality, Atascadero, CA: Ridgeview Publishing Company.

— (1981), "Mental Events", Philosophical Studies, 39.

Williams M., (1999), Groundless Belief: An Essay on the Possibility of Epistemology, $2^{\text {nd }}$ ed., Princeton, NJ: Princeton University Press. 